\title{
The Mixture of Fortune and Sweats: The Success of Korean LCD Industry in East Asia
}

\author{
In-Soo $\mathrm{Han}^{1} \&$ Keun-Yeob $\mathrm{Oh}^{2}$ \\ ${ }^{1}$ Department of Business Administration, Chungnam National University, Daejeon, Korea \\ ${ }^{2}$ Department of International Trade, Chungnam National University, Daejeon, Korea \\ Correspondence: Keun-Yeob Oh, Department of International Trade, Chungnam National University, Daejeon, \\ Korea. Tel: 82-10-2558-7805. E-mail: kyoh@cnu.ac.kr
}

Received: October 16, $2013 \quad$ Accepted: November 18, $2013 \quad$ Online Published: December 29, 2013
doi:10.5539/ass.v10n2p126

\begin{abstract}
This paper investigates the success factors of the Korean LCD industry in East Asia. These factors are described in relation to two contexts: the favorable environment surrounding the Korean LCD industry and the strategies and competencies developed by Korean companies. Success, including that of a specific firm, is usually not achieved, solely, by the efforts of a single player; it requires generally favorable conditions in the outside environment. Market conditions and rivalry among competitors are discussed as environmental factors favorable to Korean companies. Regarding the controllable strategies that Korean firms took to become top of the world's LCD industry, three (technology development, investment, and manufacturing) are explained in detail. Various competencies that enabled Korean firms to develop these strategies are also mentioned. Finally, the discussion in the paper implies that business success can depend on intuition or risk-taking as well as reasoned decision making.
\end{abstract}

Keywords: LCD panel, Korean LCD industry, success factor, display, East Asia

\section{Introduction}

Korea's flat-panel display (FPD) industry has been very successful, especially in the thin-film transistor (TFT)-liquid crystal display (LCD) area. Korean firms, together with those from Taiwan, now account for more than $80 \%$ of the LCD panel market. Although Korean firms still import many materials and components from Japanese firms, the Korean companies Samsung and LG dominate the LCD panel market. These two big firms represent more than $50 \%$ of the world market. Furthermore, the market is expected to expand in the future, which seems likely given the LCD TV situation. Indeed, in this sector, the Korean firms' positions, at the top, seem secure for the time being.

Until the late 1980s, there was no LCD industry in Korea. All the LCD panels it needed to produce the monitors of laptop computers were imported from Japan. However, in the 1990s, Korean companies succeeded in developing their own LCD panel technologies and expanded their market share in the panel sector, although they still relied primarily on Japanese firms for materials and components as well as manufacturing equipment to produce the panels. Thus, it may seem unbelievable that, since then, Korean firms have caught up and have now surpassed the Japanese firms, who were the pioneers and leaders and in the industry. How did they manage to become the new leaders in this sector? This is exactly the sort of question researchers are curious about.

The paper was written in response to that question. Previous literature reports do not seem to have answered the question adequately. Indeed, there are few articles on Korean firms' success in the LCD industry and, those that were undertaken, were relatively basic in relation to the whole picture and were full of ad hoc explanations. However, in this paper, we explain the success factors of the Korean firms using framework that addresses two key aspects: favorable environmental factors and controllable strategies and competencies. We hope this explanation has general implications for firms in developing countries, and for other firms who want to invest their money in new, cyclical, and dynamic markets.

\section{The Entry of Korean Companies in the LCD Industry}

The barriers to enter in the LCD industry are extremely high for any company that wants to become involved in fabricating flat panels. If we consider the investment needed to be of the order of US \$2 billion, this is not an 
industry for amateurs. So, what made the Korean firms interested in this kind of challenging market? Even though Korean firms began to be interested in LCDs from the late 1980s, the Koreans entered their stride in the early 1990s (LG Story, 2008). Samsung established the AM-LCD division in 1991 and launched a team in R\&D in April 1991. LG built a pilot line in their research institute and the LCD division was formed within LG Electronics in 1991. Hyundai Electronics was a little earlier than the other companies. It established its LCD division in 1989. It was common practice among these companies that the LCD business started as a small research team and expanded to a business division; finally, they evolved into a separate company, as time went on.

While each company had its peculiar background in terms of the new business, they all shared the expectation that the LCD market would grow rapidly in the near future. High growth in the computer products market was one of the rationales for this. As those companies were producing and exporting the electronics, and most of the electronics needed LCD displays at that time, they thought the TFT-LCD market would be enormous. Additionally, demand for laptop computers, and monitors for them, was exploding. However, the market was still totally dominated by the Japanese firms at that time, so while there was a chance for the Korean firms, it could still be risky.

One compelling reason why the Koreans firms wanted to get into the industry directly was their desire for technological independence. They thought that they could not survive if they did not have their own LCD technology. At that time, Korean laptop firms were competing with Japanese firms, but their production was limited by the supply of Japanese LCD screens. After experiencing this drawback, Korean firms wanted to develop the technology for themselves rather than secure OEM deals with Japanese firms, showing a clear difference between Korean and Taiwanese firms.

It appears that Koreans have strong feelings of independence from other countries. Some say it is derived from Koreans' painful memories of past colonial days. The desire for independence was realized in the industrial arena and resulted in technological independence. Korea pursued its own LCD technology development, and Korean firms tried to reach new standards, beyond those of other advanced countries, to escape from dependency on those countries.

So, it was natural that Korean firms did not have adequate technology when they entered the industry. However, they did have precious assets: confidence, and learning effects that they had gained from their experience in competition in the semiconductor industry. They enjoyed higher yield rates in DRAM production than Japanese companies, and succeeded in the development and mass production of the world's first 64k DRAMs, ahead of Japan, which would help them in developing LCD technology and commercializing it. Their success in the semiconductor industry resulted in these companies having the confidence to develop another unknown LCD technology, thus proving the proverb, "Nothing succeeds like success."

The need for diversification of products was considered another reason for entry into the LCD industry. For example, Samsung Electronics thought the semiconductor market was too unstable to secure consistent revenues. Furthermore, it expected that the LCD business could offer very large synergy effects with the existing semiconductor sector (Kim, 2001).

\section{The Favorable Environment to Korean LCD Companies}

Success-including a firm's success-is usually not achieved, solely, by the efforts of the player; it also requires generally favorable conditions in the outside environment. These external environmental factors are basically uncontrollable by the firm's efforts, although, to some degree, the firm can manipulate some aspects of the environment in its favor. We consider the market and competitors as two major uncontrollable factors in the situation that the Korean LCD industry faced.

\subsection{Market}

Two aspects of the LCD market need to be considered to explain the development and expansion of Korean LCD companies.

\subsubsection{Expansion of the Market}

The general expansion of the LCD market was responsible for a major part of Korea's success in the LCD industry. This expansion was possible due to the generally widening applications of LCDs and victory in the contest with other FPD technologies.

First, the variety of applications resulted in an overall larger demand for LCDs. In the early stages, LCDs were used only for the digital displays of watches and calculators but LCDs gained a new use in laptop computers in 
the late 1990s, followed by further new uses in various IT product displays, including cell phones, personal digital assistants, hand-held video game systems, navigation systems, and projectors in recent years. Above all, the PC monitor of the early 2000s and LCD TVs of the mid 2000s played critical roles in increasing the market generally for LCD panels.

This expansion in applications was possible because of the slashed production costs, due to technological advances in producing larger-sized substrates, and increased productivity. For example, cutting the prices of large-sized panels resulted in the replacement of CRT monitors by LCD monitors for desktop PCs. Further, it encouraged the demand for larger monitors and then LCD TVs, which, in turn, further expanded the market.

Second, technological advantages of TFT-LCDs also contributed to the expansion of the market. Thin-film transistor liquid crystal displays (TFT-LCDs) are a type of liquid crystal display (LCD) that use thin-film transistor (TFT) technology to improve image quality. In a short time, TFT-LCDs became the standard LCD product because they could display video movies with a colorful display.

As an example of the technology advantage, we can compare LCDs with plasma display panels (PDPs) in the TV screen market. The two displays competed fiercely in the market at that time, with their own strengths and weaknesses. PDPs had advantages over LCDs in the following respects (Ramsy \& Pendlebury, 2007):

1) Plasma screens could display black more accurately than LCDs, meaning better contrast and more details in dark scenes.

2) Plasma screens typically had better viewing angles than LCDs.

3) It was said that LCD screens had a tendency to blur images, particularly during fast moving scenes in movies or in sports because the pixel response time of LCDs is slower.

4) Plasma screens were cheaper than their LCD cousins, particularly in the large screen end of the market.

In contrast, LCDs had some advantages over PDPs in that LCDs tended to have higher native resolution, tended to consume less power, and to have longer lifespan than plasma screens. As a result, the flat-panel television market was segmented fairly clearly: LCD sets were available only in screen sizes smaller than 40 inches and PDP products were available in larger sizes, over 40 inches.

However, these comparisons were only true then, for older-generation LCD screens. In fact, the technology in LCD production improved greatly over a short time and overcame many of the previous weaknesses of LCDs. Furthermore, mass production of LCDs in large screen sizes became possible, which, in turn, reduced prices for LCD production. A critical change at that time was the rapid transition in TV resolution from 'HD' level to 'Full HD' level. With this change, PDP technology was not able to compete with LCDs in terms of electrical power consumption and production costs. As a result, technological advantage and continuous technology development were major factors in the market expansion.

\subsubsection{Cyclicality of the Market}

Because the large market expansion was a good opportunity for all market participants, those changes did not provide any special advantage to Korean firms but benefitted other firms too. However, other idiosyncratic characteristics in the market during the process of market expansion facilitated the success of Korean firms in the LCD industry. Changes in demand for LCD panels showed a cyclical, not linear, structure. That is, the LCD industry has a business cycle, which has ups and downs, like the semiconductor industry. The shape of the cycle is determined by the overall IT business cycle and the capacity of suppliers. The cycle in the LCD industry has been called the 'Crystal Cycle', like the 'Silicon Cycle' in the semiconductor industry (See the Figure 1). 


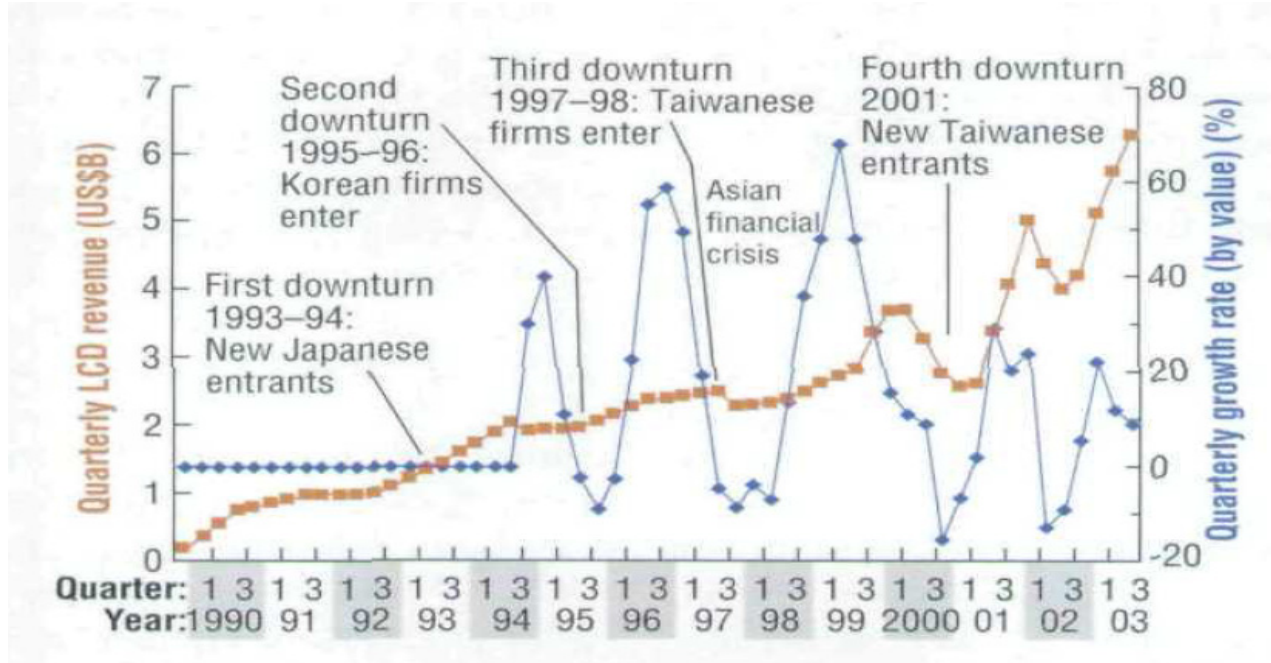

Figure 1. The crystal cycle and strategic initiatives

Source: Mathews (2005).

What causes this Crystal Cycle? Price cuts for panels in a recession period gave rise to new demand for panels, which resulted in a shortage of supply (Mathews, 2005). This excess demand encouraged the firms to invest a lot in production facilities because they expected to reap larger profits. Then, the firms have a generally larger capacity for production. On the other hand, the price rise will reduce the demand for LCDs and the resulting excess supply of LCDs will make prices go down. Price decreases lead to decreases in investment and supply. The market again faces a shortage of products, which pushes prices up again. In short, the LCD industry has repeated downturns and upswings because of supply-demand imbalances.

This feature of business cyclicality is one of the critical factors in the environment that increases risk and uncertainty for individual firms, and firms can suffer from difficulties in decision-making. However, Korean firms used this uncertainty very well in the process of their business success; they made very effective and efficient decision-making processes to overcome uncertainty in the business cycle.

As an example, Samsung and LG made aggressive countercyclical investments and this strategy proved to be very successful. Indeed, they made large and aggressive investments twice.

First, Samsung and LG entered the industry through aggressive countercyclical investment in 1995-1996, using the newest, 3rd generation fabrication equipment while, at the same time, other market incumbents were being forced to pull back on their investments. It required a particular kind of courage, or daring, to engage in such countercyclical investments. The firm poured investment funds into an industry at the very time when prices were falling, production is falling, and other firms are cutting back-and with no end in sight. However, the decision was based on the belief that the downturn would be followed by an upswing.

Indeed, the upswing came, in 1996-1997, and the Korean firms were able to profit from it, as were the Japanese incumbents. The competitive dynamics were now being driven by the new entrants, who moved to larger substrate lines for their panels, enabling them to produce panels for new applications, including larger-screen laptops and, for the first time, desktop monitors.

Aggressive countercyclical investments were made once again in the early 2000s, which resulted in a complete change in the market (Han et al., 2012). Korean firms were much encouraged by the success of the third-generation investments and became more confident of their business. Thus, when a new recession in the LCD market occurred because of the technology bubble collapse, the firms made another big investment in 2002-2003. Of course, this was possible because the Korean firms were expecting another expansion of the market for LCDs, due to the increasing demand for computer monitors. In conclusion, the Korean firms' bets were very successful. From the latter half of 2003 through 2004, demand for laptop computers increased rapidly, and Korean firms took advantage of the situation. In short, risk-taking investments by Korean firms played a ground-breaking role, and they became the leading companies, ahead of the Japanese firms. 


\subsection{Rivalry against Competitors}

The competitor factor is important in determining the competitiveness of a firm (Porter, 1999). In the LCD industry, Korea has three major competitors: Japan, Taiwan, and China. While China seems to be a potential competitor for the future, Korea succeeded in the market in competition with Japan and Taiwan. What is known about rivalry between Korea and these countries?

\subsubsection{Japan}

The Japanese LCD industry had set up almost insurmountable barriers to the Korean LCD industry. Japan first transformed LCD technology concepts, invented in the US, into commercial products such as the early displays of digital watches and electronic calculators. Japan was truly a pioneer and dominated the LCD business until the Korean firms managed to enter it. Japan took almost $100 \%$ of the world LCD market before Korean companies entered the market in 1995. Furthermore, Japan had a complete system for producing LCD-related items: from upstream products, such as materials, components, and manufacturing equipment, to downstream products, like the panels themselves and other final products.

How could Korean firms challenge such a technological and manufacturing base? How could they catch up and even surpass those leaders? Figure 2 shows that the gap between Korea and Japan had narrowed as time went on after Korea entered the industry. Finally, Korean firms surpassed the Japanese firms in 2001. Many agreed that it was possible not only because Korean firms had performed very well but also because Japanese firms made repeated mistakes in terms of strategy (Nakata, 2007; Shintaku, 2008).

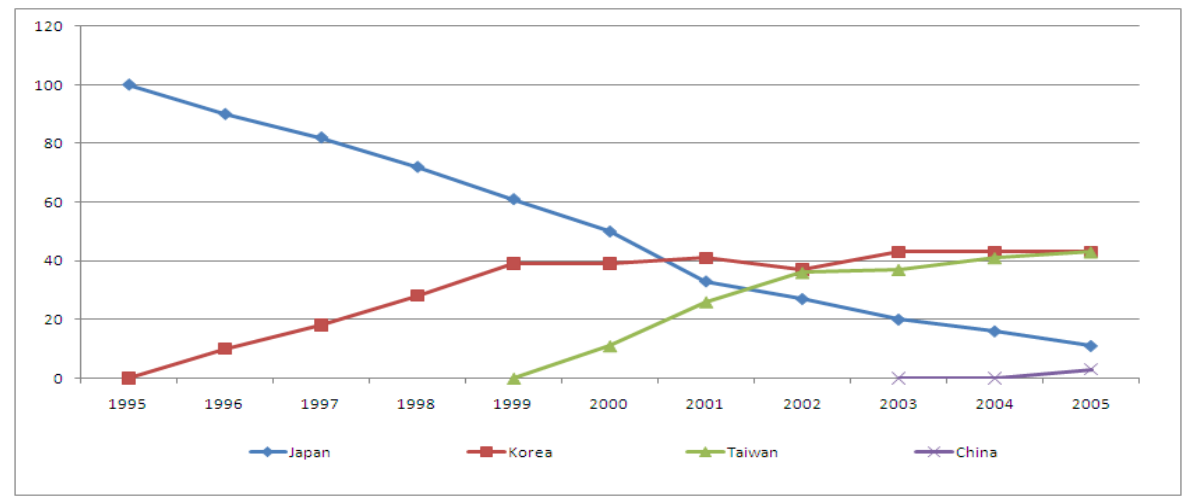

Figure 2. Trends in market share by country in the large-sized LCD panel market

Source: Shintaku (2008).

Japanese firms made a couple of strategic mistakes by hesitating with regard to investments. They repeatedly missed timely investments. The first situation occurred in 1996. At that time, the Japanese firms were world-leaders and had been putting money into the industry step-by-step: first, 2nd generation (10.1 inches) panels; second, 2.5th generation (11.3 inches) panels; and then the 3rd generation (12.1 inches) panels. Those investments followed changes in monitor market trends. In contrast, Korean firms moved directly to 3 rd generation panels, without getting into earlier generations. By that time, the market was moving from 10.1-inch panels to 12.1-inch panels without going through 11.3 inches. Because of the big jump in the market, the entering Korean firms were very successful. Compared with Japanese firms, which lost a lot of money, Korean firms took the chance to catch up with the Japanese firms (Chang, 1999).

The next failure of the Japanese firms happened in the early 2000s (Fujimura \& Sato, 2010). Japanese firms did not invest heavily, relatively speaking, at that time for various reasons, while the Korean firms made very aggressive investments. In fact, Japanese LCD firms had made a lot of money in the IT boom period and they did invest almost three times more than the average in previous periods. However, right after those investments were made, the IT bubble burst in 2000-01. Because the Japanese firms' investments depended on how much they had earned in the previous year and their earnings were negative in 1998-2002 (Table 1), they could not invest heavily. In contrast, Korean firms, who also made a lot of money in the IT bubble period, could invest very aggressively, using their earnings. 
Table 1. Performances of the LCD industry in the three countries and their investments (1998-2002) (million Yen)

\begin{tabular}{llll}
\hline & sales volume & operating income & facility investment \\
\hline Korea(2companies) & 21,012 & 4,393 & 7,517 \\
Japan(6companies) & 41,679 & -191 & 7,028 \\
Taiwan(5companies) & 12,682 & -73 & 8,981 \\
\hline
\end{tabular}

Source: Nakata (2004), p.56.

In addition to this background information, the Japanese management style could be another reason why they missed making timely investments. The Japanese are, generally, very deliberate in decision-making. They are also sometimes known to be risk-averse.

Another important reason for the Japanese firms' failures in LCD investments was the inability of the top managers to predict market changes correctly.

For these various reasons, Japanese firms failed to invest in newer generation LCD technology. As a result, market power transferred gradually to the Korean LCD companies. The only exception was Sharp (Table 2) and this firm survived in the industry despite the generally declining trend of the Japanese LCD panel industry.

Thus, most Japanese firms, except Sharp, lost their market leadership positions in panel manufacturing. However, thanks to their high-level technology, they are still competitive in materials, components, and manufacturing equipment. Thus, if Korean firms continue to be successful, the Japanese firms in these sectors would be expected to grow consistently in the future too.

\subsubsection{Taiwan}

In recent years, Taiwan's firms have been another strong rival in the panel manufacturing industry for Korean firms. Taiwanese firms entered this market in 1999 for the first time. While Korean firms developed their technology independently of Japanese firms, Taiwanese firms came into the market by getting the needed technology from Japanese firms via technology licensing.

Why did Japanese firms transfer their LCD technology to Taiwan, while they opposed doing so to Korean companies? There were several reasons for this.

First, Japanese firms wanted to fend off the Korean firms' challenge. At that time, Korean firms were trying to get into the laptop PC monitor market by taking advantage of the lower exchange rate. Due to the East Asian financial crisis, the Korean Won was very weak. Thus, Japanese firms were concerned about the dominance of Korean firms in the Taiwanese market and provided technology licenses to the Taiwan firms.

Table 2. Investment rankings of the major LCD companies (1999-2003)

\begin{tabular}{llllll}
\hline Year /ranking & 1999 & 2000 & 2001 & 2002 & 2003 \\
\hline 1 & AU Optronics & AU Optronics & Chi Mei & Samsung & Sharp \\
2 & Samsung & Sharp & L.G.Philips & AFPD & L.G.Philips \\
3 & HanStar & Samsung & HanStar & AU Optronics & Chi Mei \\
4 & L.G.Philips & L.G.Philips & Sanyo & L.G.Philips & Toppoly \\
5 & Chi Mei & CPT & Sharp & Quanta & CPT \\
6 & Hyundai & Toshiba & ST LCD & Sharp & AFPD \\
7 & Hitachi & Chi Mei & CPT & Toppoly & Quanta \\
8 & Toshiba & Hydis & Hitachi & Sanyo & Hitachi \\
9 & DTI & IDTech & Toshiba & Hitachi & SVA-NEC \\
10 & Jilin & Quanta & Quanta & Chi Mei & Hanatar \\
\hline
\end{tabular}

Source: Matsuno (2003). 
Second, there was high cost problem for producing TFT-LCD in Japan. Although the costs of materials and components were relatively low, wage and R\&D costs were relatively high in Japan and, thus, the margin rate was lower, by $8 \%$, than Korean firms, and $10 \%$ lower than Taiwanese firms (Akabane, 2004; Nakata, 2007). From this point of view, technology transfer seemed to be the inevitable choice for the Japanese firms' management strategy. After the technology transfer, Japanese firms then imported earlier-generation panels from Taiwan for original equipment manufacturing (OEM).

However, in a very short time, Taiwanese LCD firms made great advances, even though the technologies transferred to them were not then state-of-the-art. Their growth was beyond everyone's expectations (Hsiao et al., 2011).

Regarding the remarkable success of the Taiwanese LCD industry, the following factors can be mentioned.

First, the success of the Taiwanese LCD industry owed much to government support. The Taiwanese government was very active in that they designated this industry as a strategic industry at the national level and they established the government-sponsored "Industrial Technology Research Institute" (ITRI) to support the technological development of LCDs (Wang, 2007).

Second, Taiwan had already accumulated experience and operating know-how from producing a variety of IT products, including PCs and semiconductor foundries, which, in turn, contributed to their success with another IT product, LCDs (Chang, 2005; Hung, 2006).

Third, the fast follower strategy often adopted by Taiwanese LCD companies attracted the attention of some analysts as another success factor in the Taiwanese LCD industry. The fast follower strategy, sometimes called the second mover, is a strategy that follows the first mover who enters the market first with a new product. This strategy can sometimes even have some advantages over the first mover. Taiwanese LCD companies made full use of their position as a fast follower (Mathews, 2005; Shintaku et al., 2006).

Based on their success, the Taiwan LCD industry grew rapidly and reached the world number two spot, followed by Japan in 2002. In 2004, Taiwan ranked first in the world in terms of quantity, followed by Korea. (Yun et al., 2010)

However, the Taiwanese firms had some inherent weaknesses because they started their businesses by relying on licenses from, and OEM for, Japanese companies (Han, 2007). Furthermore, firm size is another handicap for the Taiwanese. The companies are relatively small, compared with those in Korea and Japan, which can sometimes give the firms difficulties in launching a major project. M\&A among LCD firms has been more common in Taiwan than in Korea. It has been said that Taiwanese firms had more difficulties after the global financial crisis, and the gap has been widening between Korea and Taiwan. In recent years, Taiwanese firms have tried to expand a strategic alliance with Chinese firms to overcome these issues.

\section{The Strategies and Competencies of the Korean LCD Companies}

Next, we explain the controllable strategies that Korean firms took to become top of the world's LCD industry. Various competencies that enabled Korean firms to adopt these strategies will be also mentioned.

\subsection{Technology Development Strategies and Contributing Competencies}

It was to be expected that the Japanese firms, the leaders in the industry, did not welcome the Korean competitors; indeed, they wanted to keep Korean firms from becoming new competitors in the LCD market. Thus, Korean firms could not expect any technology transfer from the advanced Japanese firms and they had to develop the technology for themselves, from the beginning.

Technology development began with reverse engineering, as had been seen in other technology development in Korean industries before (Lee et al., 2008). Small task forces were formed and supported by the top management at the firms. At first, they bought Japanese LCD products and disassembled them. They repeated the process, analyzing how the products were made. For example, LG began its research with a 5.6-inch product, bought for 700 dollars (LG Story, 2008). Samsung is known to have disassembled more than 1,000 Japanese products to gain access to application-specific integrated circuit (ASIC) technology (Kim, 2001).

The Korean LCD industry, which had started from almost nothing, succeeded in producing test products in October 1994. LG invested 400 million dollars to build its LCD factory in its Kumi factory in August 1995. In 1996, Hyundai Electronics joined the market by building a production line in the city of Inchon.

When it comes to the competencies that contributed to the success of the technological development of LCDs, three can be considered: accumulated knowledge from the semiconductor industry, enthusiasm of qualified young engineers, and rivalry among conglomerates. As mentioned earlier, Korean firms' success in LCD 
technology was partly attributed to competencies and experiences accumulated in the semiconductor industry. Of course, LCD panels were new to the Korean firms, but it was known that many production procedures for LCD panels were similar to those of semiconductors. Thus, some of the Korean firms' technology could be applied directly in the new industry. Additionally, abundant qualified human resources and their enthusiasm can be mentioned as another factor in their development success.

Samsung, LG, and Hyundai, major business conglomerates in Korea, sought to recruit excellent individuals, armed with challenging minds and passion, both domestically and from abroad. These people were ready to do their best to compete with the Japanese firms. Because technology transfer was rejected by the Japanese firms, development team members visited sites and firms worldwide and searched for technology sources by themselves. Legendary stories abound about these times, showing the great efforts that were made. When the first production line was built, the task force of 30 workers did not go home for a week in order to check the line and reduce the defects (LG Story, p. 20). "Seven to eleven" was not unusual at that time; many workers worked from seven in the morning to eleven in the evening. Despite the technological handicaps, young Korean LCD workers had enthusiasm and a target--to surpass the Japanese firms' technology--even though it looked almost impossible at that time. They sought to improve productivity and to develop an independent technology with which they could respond to new trends in the market.

The rivalry between Samsung and LG, two leading conglomerates in Korea, was another important motivation in the technology development. The two groups had been competing for a long time in Korean business history. It is true that serious rivalries can sometimes turn out badly, but in the LCD industry it gave rise to positive effects. The two groups were sometimes competing and, at other times, cooperating.

Although we admit that Korean firms developed independent technology in TFT-LCD, it would be more accurate to say that the all of the technologies were not developed completely independently. Technology transfer and learning based on it can be found here and there (Kim, 2002). Moreover, some would say that technology leakage from Japanese firms occurred too (Nakata, 2007). In the early 2000s, when the Japanese firms were hesitating to invest much money in this uncertain area, Korean firms were actively taking the risk and investing heavily, meaning that the Koreans firms were large and important customers of the Japanese manufacturing equipment companies. As a result, some Japanese manufacturing equipment firms were, intentionally or unintentionally, helping Korean firms to obtain the technology. Sometimes, retired engineers from Japanese firms could be another conduit for the technology leakage (Nakata, 2007). These explanations may all be true in part, but synthesizing the separate technological aspects would not have been possible without the Korean firms' constant efforts and competencies.

\subsection{Investment Strategies and Contributing Competencies}

There is no objection to the argument that one of the most critical factors for the Korean LCD industry's success was timely investment by top decision makers. These decisions would not have been easy in that aggressive countercyclical investments were made at a time of recession. It seemed very risky; fortunately, however, there were new applications that resulted in increased demand for LCDs and subsequent increases in profits for Korean firms. That is, a virtuous circle occurred: "Big investment in a recession $\rightarrow$ increased demand $\rightarrow$ fruits from the investment $\rightarrow$ new investment into new-generation LCDs." This ultimately moved the Koreans firms to the top of the LCD industry.

The investment by Korean companies was very timely when we recall that there was a big trend in consumers seeking larger and larger display monitors, resulting in increased demand for larger LCD panels. In particular, because of the unique characteristic of the LCD industry, that the panels became larger and larger was important for improving competitiveness (Nakata, 2007). In the process of panel production, a couple of panels are obtained from a substrate and the edges of the substrate are then useless. Thus, a higher proportion of usable area results with large substrates and larger substrates can help in competitiveness and economies of scale.

Thus, LCD panel companies sought advanced new-generation production lines in which the substrates produced were larger than before. It is well-known that in LCDs, the 'generation' is defined by the size of the substrate. However, it is not easy to simply invest for the production of larger substrates. For an advanced-generation production line, the cost was a couple of billion dollars, even in the 1990s and it took at least 2 years to build a new line. Thus, the companies had to take big risks to move to newer-generation models. Their decisions had to be based on correct demand forecasting and accurate predictions of the market situation in the future.

At this point, there was a big difference between the Korean firms and Japanese firms. As mentioned before, there were two chances for the Korean companies to gain in competitiveness over the Japanese firms. The first occurred in 1995-1996; Korea succeeded in investing in third-generation lines. Another opportunity occurred in 
the midst of the IT bubble, when they, fortunately, were able to take advantage of the demand boom for laptop computers and LCD monitors.

Table 3 shows that Koreans were very successful in the LCD industry from 2000 to 2005 (Bok, 2007). LCD production enjoyed a $28 \%$ growth rate after the year 2000, which resulted in revenues of 20 billion dollars in 2005 . The exports of LCD panels and related products had been growing at a rate of $12.8 \%$ per year, which made LCD panels one of the largest exports of the Korean IT industry.

Table 3. TFT-LCD output and production trends in Korea (2000-2005)

\begin{tabular}{|c|c|c|c|c|c|c|c|}
\hline & 2000 & 2001 & 2002 & 2003 & 2004 & 2005 & $\begin{array}{l}\text { Annual growth rate }(\%) \\
(2001-2005)\end{array}$ \\
\hline $\begin{array}{l}\text { panel output } \\
\text { (Market share \%) }\end{array}$ & $\begin{array}{l}11.4 \\
(37.2)\end{array}$ & $\begin{array}{l}18.5 \\
(40.8)\end{array}$ & $\begin{array}{l}25.4 \\
(37.0)\end{array}$ & $\begin{array}{l}43.8 \\
(43.9)\end{array}$ & $\begin{array}{l}61.4 \\
(44.4)\end{array}$ & $\begin{array}{l}89.4 \\
(44.2)\end{array}$ & 48 \\
\hline $\begin{array}{l}\text { amount of production } \\
\text { (Growth rate \%) }\end{array}$ & $\begin{array}{l}6,346 \\
(34)\end{array}$ & $\begin{array}{l}8,946 \\
(41)\end{array}$ & $\begin{array}{l}10,211 \\
(14)\end{array}$ & $\begin{array}{l}14,979 \\
(47)\end{array}$ & $\begin{array}{l}21,388 \\
(43)\end{array}$ & $\begin{array}{l}24,344 \\
(14)\end{array}$ & 28 \\
\hline
\end{tabular}

Source: D. Bok et al. (2007).

On top of this, the LCD TV market emerged, providing new demand for LCD panels from 2004, following the boom in laptop computer and desktop monitors. Thanks to the new market for LCD TVs, Korean companies were doing their best to invest money into larger panels. Samsung and LPL spent about 2 billion dollars for the production of a 7th generation production line every year from 2003 to 2005 . This investment made it possible for LPL to operate a 6th generation line in 2004 and a 7 th generation line $(1950 \mathrm{~mm} \times 2250 \mathrm{~mm})$ in 2005 . In 2005 , Samsung launched a 7th generation $(1860 \mathrm{~mm} \times 2200 \mathrm{~mm})$ line in partnership with Sony, which was the leading line at that time. To date, the Korean firms have maintained their lead position in LCD technology. The only exception was when Taiwan gained the top spot in 2005, in terms of production quantity. In terms of sales, Korean firms have continued to lead, because the prices of Korean LCD panels are higher than those of the Taiwanese due to the size of the panels.

The LCD market had some difficulties in 2008 due to the global financial crisis. However, it had recovered to a better situation in 2009 , because there was a big increase in demand for larger panels. Korean firms, which produced large panels for TVs, could take advantage of this. Since then, Korean LCD producers have enjoyed the upturn in the business market.

So, which factors made the Korean firms make such countercyclical investments in an industry that looked very risky and unstable? One answer can be found in Figure 3, showing that new applications of LCDs and the demand boom for LCDs followed the big investments, and the Koreans firms then benefitted from good earnings.

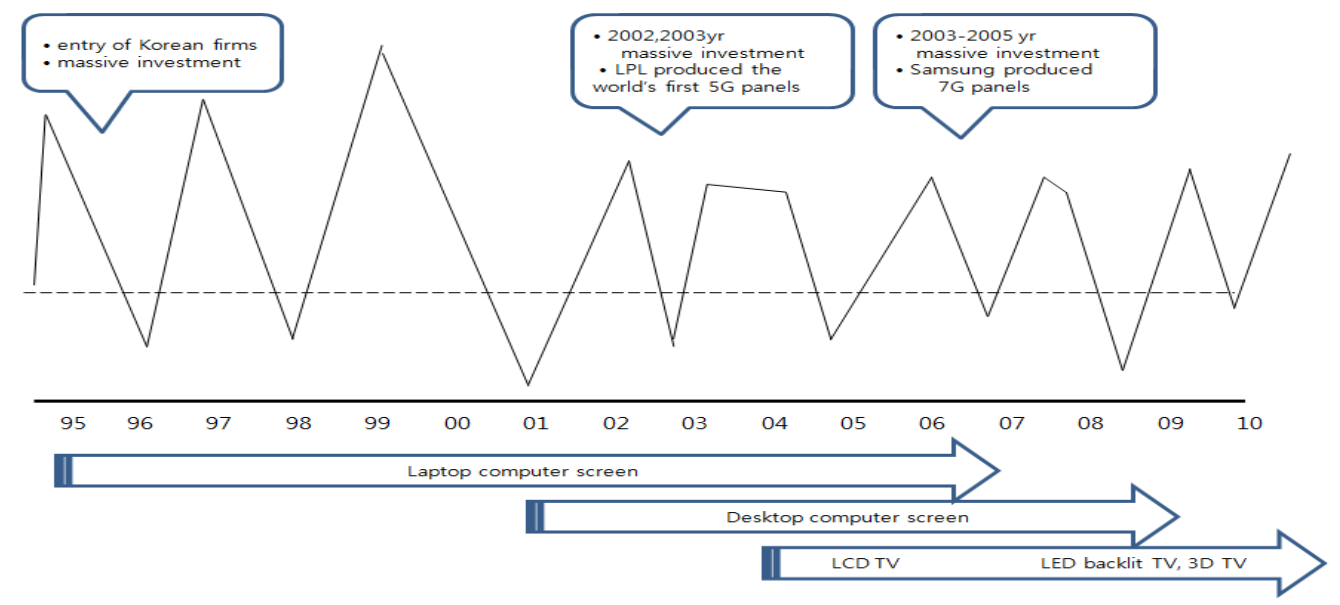

Figure 3. Match between the investments of Korean LCD companies and increasing applications and demand 
Can we simply say that this success of the Korean firms was because they were lucky? Absolutely not. It is more rational to say that they were calculating and predicting the size of demand quite correctly, well in advance.

For example, the success in 1996 was possible because Korean firms correctly predicted that there would be a big demand for large panels, while Japanese firms did not think about this in the same way. Korean companies invested a lot in $3^{\text {rd }}$ generation production lines, based on this prediction at that time. In 2002 and 2003, with the expectation of strong demand for laptop computers and PC monitors, LPL (LG Phillips) began to operate a 5G fabrication factory, the first in the world. Big investments in 2004 and 2005 were possible based on the belief of a demand boom for LCD TVs.

Several contributing competencies can be identified as the factors for these appropriate and timely investments. The first is that of the strategic decision-making abilities of top managers at Samsung and LG, which enabled accurate predictions of market trends. The second is the merit of the owner management system, as pointed out by many scholars. As is well-known, Samsung Electronics Co. and LG Display belong to the Samsung and LG conglomerates, respectively. These two groups are characterized by very strong owner influence. When owners support the mangers' decisions, the firms could comparatively easily invest large amounts of money even into potentially risky businesses.

A third factor was that of resources for the major investments. As noted above, very large sums of money were needed for building advanced-generation LCD lines. Korean companies, fortunately, could mobilize the needed money for these investments. To understand this, we need to pay attention to the business structure of Samsung and LG conglomerates. Samsung Electronics Co. (SEC) consisted of three major divisions: semiconductors, mobile, and the display division, including LCD production. Samsung could use internal reserves accumulated during the semiconductor boom period. In LG's case, while it is true that the LCD company is a separate company, it could also be considered as a division of other external companies because LPL borrowed a lot of money from other companies within the LG conglomerate. LG had financial difficulties in building more production lines in the Asian currency crisis period. Thus, LG established a joint venture, LG Philips (LPL) with Phillips to secure a stable investment. At that time, a third LCD company, the LCD department of Hyundai Electronics, was separated from the parent company and renamed as Hydis because of the parent company's business troubles. After that, Hydis was sold to BOE Group of China. Thus, the Korean LCD industry was rearranged into a two-tier system.

Of course, internal reserves were not enough for the amounts invested, so the firms sometimes relied on external sources too. Because the LCD industry was a strategic one for the Korean economy, they could borrow a lot from government-sponsored banks at low interest rates. This advantage should not be ignored when discussing the success factors of the Korean LCD industry.

\subsection{Manufacturing Strategies and Contributing Competencies}

Manufacturing strategy also contributed to the competitiveness of the Korean LCD industry. Making high quality products at low cost is a key factor for high competitiveness in the market. Korean LCD firms implemented the following strategies for high yields and low costs.

First, they tried to localize materials and manufacturing equipment, if possible, to keep costs down. Because the Korean LCD industry grew initially through so-called reverse engineering, they were relatively weak in the production of upstream lines: materials, components, and manufacturing equipment. Indeed, they imported most of these products from Japan. This was a big weakness for Korean firms in the beginning and they tried to overcome this problem by localizing the production process. Vertical integration was the way Korean firms took at that time for the production of materials, components, and manufacturing equipment. That is, affiliate companies were asked to produce these upstream products. This is why many vendors for Samsung and LG are affiliate companies, and why some of the owners of the LCD vendor companies are close relatives of, or retired personnel from, Samsung and LG.

Second, Korean LCD firms tried to improve the interchangeability of parts and this was helpful in improving competitiveness (Shintaku, 2008, p. 65). For the large LCD panels, almost $60 \%$ of the cost is parts-related. In particular, the cost for producing the glass substrates is $30 \%$ of the panel's cost. Thus, it is important for the panel producers to have a stable supply of glass substrate. However, if a certain panel company uses only a specific substrate, it may become dependent on one glass substrate supplier. This would mean that the company would not have bargaining power in deciding the price of glass substrates.

Thus, the firms sought to get out of this situation and they developed new manufacturing processes that were independent of any specific glass substrate. This happened around the $4 \mathrm{G}$ generation period and, since the 
production of $5 \mathrm{G}$ panels, they have succeeded in being able to choose glass substrate from many suppliers. For example, although Samsung has a close relationship with Samsung Corning, Samsung continued to have two companies as partner suppliers and this was helpful to keeping costs down by making the two companies compete with each other. Samsung Corning now supplies substrates to LG too.

Third, improvement of production facilities through close cooperation with the manufacturing equipment companies helped Korean firms a lot (Shintaku, 2008, p. 68). Japanese equipment makers generally leave the factory after they install the lines and confirm that everything works well, and the panel makers take on the responsibility to operate them by themselves. However, in Korea, closer relationships between panel makers and equipment makers lasted longer because the Korean equipment engineers typically resided in the factory for long time periods after installation. Furthermore, it is usually said that Korean equipment makers tend to be more effective at improving the production process.

One of the competencies that Korean companies have relating to manufacturing is that of their high yield rates and cost competitiveness, mainly from accumulated experience in the process of producing semiconductor products. As a matter of fact, the Korean makers had considerable capability with regard to handling operating processes and managing yield rates. In particular, the Korean yield rate is known to be one of highest in the world. For example, the yield rate of Samsung Electronics is almost $90 \%$, which is not achieved in other countries (Bok et al., 2007).

The strategies and competencies discussed so far are summarized in Table 4.

Table 4. Strategies and competencies of Korean LCD companies

\begin{tabular}{|c|c|c|}
\hline & Strategies adopted & Contributing competencies \\
\hline $\begin{array}{l}\text { Technology } \\
\text { development }\end{array}$ & - reverse engineering & $\begin{array}{l}\text { - accumulated knowledge from the semiconductor } \\
\text { industry } \\
\text { - enthusiasm of qualified young engineers } \\
\text { - rivalry among conglomerates }\end{array}$ \\
\hline Investment & $\begin{array}{l}\text { aggressive counter cycle investment } \\
\text { in downturn }\end{array}$ & $\begin{array}{l}\text { - strategic decision-making abilities of top } \\
\text { managers } \\
\text { - merit of the owner management system } \\
\text { - resources for the major investments }\end{array}$ \\
\hline Manufacturing & $\begin{array}{l}\text { - localization of materials and } \\
\text { manufacturing equipment } \\
\text { - improvement in the interchangeability } \\
\text { of parts } \\
\text { - close cooperation with the } \\
\text { manufacturing equipment companies }\end{array}$ & $\begin{array}{l}\text { - high yield rates and cost competitiveness, mainly } \\
\text { from accumulated experience in the process of } \\
\text { producing semiconductor products }\end{array}$ \\
\hline
\end{tabular}

\section{Conclusions}

In this paper, the factors that contributed to Korean firms attaining the number one position in the world LCD industry were investigated. These explanations may not be complete, but the major factors are covered in the paper. The results can be summarized as follows.

First, the LCD market has been expanded, with large increases in applications and technology advantages. However, the market expansion seems to have been not linear but cyclical. Korean firms were very aggressive in investing their money during the recession period. This countercyclical investment provided them with great opportunities later.

Second, Korean LCD firms developed their own technology and had technology leadership in some areas, which was very helpful in winning in the market. Those developments were possible partly because they had previous experience of technology development and production in the semiconductor area. LCD production processes are similar to those of semiconductors. Furthermore, young and well-qualified Korean engineers devoted themselves to the industry. The rivalry between Samsung and LG also contributed to technology development. 
Third, the success of Korean LCD firms was partly attributable to the massive investments implemented in the mid-1990s and during 2002-2005, when there was uncertainty and a downturn in the market. However, in both periods, fortunately, new applications and expanding demand for LCDs followed those investments, which made Korean firms a lot of money. These successful, and risky, decisions were possibly due not only to accurate forecasting by top managers but also because of the ownership management system of the Korean firms under examination. Additionally, rapid and daring actions to set up new production lines seemed to have contributed to the competitiveness of the LCD industry in Korea.

Fourth, Korean firms had effective manufacturing strategies. They cut costs and obtained high yield value by the strategy of vertical integration and multiple suppliers. In particular, know-how and learning effects from the experiences of producing semiconductors were very helpful in operations management. Both semiconductors and the LCD industry could synergistically affect each other within the Korean economy.

It is interesting that Korean firms were successful in an industry where the cyclical character was peculiar (the so-called Crystal Cycle, like the Silicon Cycle). Koreans were betting big money when the market was uncertain and business was in recession, and they achieved high returns when the upswing came. This was possible partly because Koreans appear to intrinsically like risk taking and tough decision-making. This composition may have matched well with the cyclicality of the LCD business. Generally, Koreans are known to be more-or-less emotional, as opposed to being entirely rational. Their success might imply that business success can depend on intuition or risk taking as well as reasoned decision-making.

This paper was written based on a literature survey and a few interviews with engineers and managers in LCD businesses. More interviews and an empirical study will be necessary for further study.

\section{References}

Akabane, J. (2004). Taiwan TFT-LCD industry: The role of Japanese companies and Taiwanese government in its development. Asian Studies, 50(4), 1-19 (in Japanese).

Bok et al. (2007). Network structure and cooperative strategies of LCD clusters in East Asia. Samsung Economic Research Institute and Japan Research Institute (in Korean).

Chang, S. C. (2005). The TFT-LCD Industry in Taiwan: Competitive advantages and future developments. Technology in Society, 27, 199-215. http://dx.doi.org/10.1016/j.techsoc.2005.01.005

Fujimura, S., \& Sato, O. (2010). Status decline of Japanese flat panel maker in LCD Industry. Akamon Management Review, 9(10), 693-674 (in Japanese).

Han, I. S. (2007). Development strategies of LCD industry in Taiwan. International Conference on Development and Globalization of Innovation Cluster in Pan-Yellow Sea Rim. Management and Economics Research Institute (MERI). Chungnam National University (in Korean).

Han, I. S., Oh, K. Y., \& Yoo, J. M. (2012). Changes in competitiveness of LCD industry of East Asia: From bamboo capitalism to water lily. International Telecommunications Policy Review, 19(1), 15-42.

Hsiao, C. T., Chang, P. L., Chen, C. W., \& Huang, H. H. (2011). A systems view for the high-tech industry development: A case study of large-area TFT-LCD industry in Taiwan. Asian Journal of Technology Innovation, 19(1), 117-132. http://dx.doi.org/10.1080/19761597.2011.578422

Hung, S. W. (2006). Competitive strategies for Taiwan's thin film transistor-liquid crystal display (TFT-LCD) industry. Technology in Society, 28, 349-361. http://dx.doi.org/10.1016/j.techsoc.2006.06.004

Kim, Y. S. (1991). New product development strategy: Samsung Electronics flat panel display decision. Management Education Review, 15(1), 123-141 (in Korean).

Lee, P. K., Jeng, D. Y., \& Kim, S. K. (2008). An in-depth case study on the expeditious technological capability building on a small and medium sized company in LCD industry. Journal of Korean Institute of Plant Engineering, 13(4), 109-122 (in Korean).

LG Display. (2008). LG Story (in Korean).

Mathews, J. A. (2005). Strategy and the Crystal Cycle. California Management Review, 47(2), 6-32. http://dx.doi.org/10.2307/41166293

Matsuno, S. S. (2003). FPD market overview and outlook. Display Search.

Nakata, Y. (2004). Flat Panel Display 2004: Practices Version. Nikkei BP Co. (in Japanese)

Nakata, Y. (2006). Japan's competitiveness in TFT-LCD industry: Analysis on the decline and a proposal for core 
national management. RIETI Discussion Paper (in Japanese).

Nakata, Y. (2007). Why Japan's LCD Industry was caught up by Korea and Taiwan. Journal of Innovation Management, 5, 141-157 (in Japanese).

Ramsy, R., \& Pendlebury, T. (2009). Plasma vs. LCD: Which is Right for You? Retrieved from http://www.cnet.com.au/plasma-vs-lcd-which-is-right-for-you-240036500.htm

Samsung Economic Research Institute. (2013). Diagnosis on current issues in Korean key Industries. CEO Information, 2(882), 1-20 (in Korean).

Shintaku, J. (2008). Manufacturing technology strategy in Korean LCD industry. Akamon Management Review, 7(1), 55-74 (in Japanese).

Shintaku, J., Kyo, K. M., \& Su, F. T. (2006). Taiwan's TFT LCD industry and business strategy. Akamon Management Review, 5(8), 519-540 (in Japanese).

Wang, S. J. (2007). Driving forces of rapid growth of Taiwan's TFT LCD industry: Meta-national perspective. RIETI Discussion Paper Series 07-J-021, 1-52 (in Japanese).

Yun, J. H. J., Park, S., Lim, D. W., \& Hahm, S. D. (2010). Emergence of East Asian TFT-LCD clusters: A comparative analysis of the Samsung cluster in South Korea and the Chimei cluster in Taiwan. Asian Journal of Technology Innovation, 18(1), 201-228. http://dx.doi.org/10.1080/19761597.2010.9668688

\section{Copyrights}

Copyright for this article is retained by the author(s), with first publication rights granted to the journal.

This is an open-access article distributed under the terms and conditions of the Creative Commons Attribution license (http://creativecommons.org/licenses/by/3.0/). 